\title{
Hoboes and Homelessness in the Midwest: A Review Essay
}

\author{
DEBORAH FINK
}

Citizen Hobo: How a Century of Homelessness Shaped America, by Todd DePastino. Chicago: University of Chicago Press, 2003. xxv, 325 pp. Illustrations, notes, index. $\$ 32.50$ cloth.

Indispensable Outcasts: Hobo Workers and Community in the American Midwest, 1880-1930, by Frank Tobias Higbie. Working Class in American History Series. Urbana: University of Illinois Press, 2003. $\mathrm{xi}, 255 \mathrm{pp}$. Illustrations, tables, notes, bibliography, index. $\$ 44.95$ cloth, $\$ 18.95$ paper.

JESUS SAID that the poor will always be with us. True so far, but do they make history? Yes, according to two excellent books about the men variously called tramps, hoboes, bums, the homeless, transients, or floating workers. Citizen Hobo by Todd DePastino and Indispensable Outcasts by Frank Tobias Higbie portray the fluid group of mostly white men who traveled the early railroads doing seasonal work in agriculture, mining, and forestry. As they traveled and worked, they built key parts of the base of the developing American economy. Beyond their work, they reinforced the demographic links between city and countryside that made the Midwest what it is. In the early twentieth century hoboes built a frankly political force that nourished progressive thought and challenged the mainstream political economy. Both despised and envied for their unfettered and undisciplined ways, hoboes continue to fascinate observers and confound conventional descriptive categories.

THE ANNALS OF IOWA 62 (Summer 2003). @ The State Historical Society of Iowa, 2003. 
The tramp nomenclature originated with Civil War veterans who were unable or unwilling to integrate into settled family and community life. The recently built railroads made it possible for them to hop freight trains and range across the country looking for work and adventure. This was an unequivocally male world, where men were freed from the fastidious habits and demands of women and steady jobs. Over time, it became a stage of life when many men, in their late teens to early thirties, would strike out on their own. Notwithstanding the adventure and romance, life on the road was a grueling, violent, lonely, and dangerous experience for most hoboes.

The pattern that emerged was for hoboes to gravitate to defined areas of major cities such as Chicago, Sioux City, and Minneapolis, where they met up, exchanged information about jobs, rested, and wintered. To work, hoboes would branch out to rural jobs harvesting wheat, cutting timber, mining, or doing other seasonal work. The city location, called the main stem or hobohemia, was the vital center of transient life. It allowed for the critical mass and social space that made possible self-identity, political development, and organization.

Such organization came in the early twentieth century, most notably with the radical Industrial Workers of the World (IWW), or Wobblies. Within the IWW, the Agricultural Workers Organization (AWO) became a strong organizing segment in the Midwest. Through speeches, newspapers, pamphlets, and songs, the IWW and AWO built a worker consciousness that stood in opposition to the image of the idle capitalist. The fat capitalist became a caricature of the forces that harvested the masculine strength of the laborer in order to build a decadent empire of power and wealth, which then excluded and denigrated the hobo, the real worker.

The IWW was among the socialist factions opposing World War I. That, together with general wartime restrictions on political expression and labor threats, provided cover for the government to crack down hard on Wobblies. Although the IWW had never been a majority movement, even within the hobo world, by the 1920s it was reduced to an ineffectual trace of its former stature and was no longer a threat to anything. In the 1930s, President Roosevelt sought to organize and contain po- 
tentially radical young unemployed males in such programs as the Civilian Conservation Corps. Increasingly in the 1940s and 1950s, settled family life emerged as the only responsible life choice, and it was promoted through multiple means, including veterans programs, urban renewal, labor agendas, and popular culture.

In Indispensable Outcasts, Higbie states, "If we view the region [Midwest] not from the floor of the Chicago Board of Trade but from the eyes of a young laborer working in seasonal industries and agriculture, we get a different picture of the links between rural and urban life" (10). Indeed. Exploring the contours of hobo experience, he points to the ironies of their absence in most social and political histories of the Midwest. Although almost certainly undercounted by census enumerators, various indicators suggest that a substantial number of employed men were "unskilled" workers, and possibly transient, in the early twentieth century. In 1919 and 1921, for example, USDA surveys of harvest hands indicated that one-fifth were transient. Exact numbers and details are notoriously hard to establish. Even with a wealth of life stories written both by reformers and by hoboes themselves, attempting to understand the hobo experience is dicey. No matter. They made the western economy work, complicating the image of the homogeneous rural community by establishing the reality of rural class division, conflict, and contradiction.

Citizen Hobo explores the meaning of homelessness as an American cultural category. DePastino investigates how the phenomenon of homelessness has shaped and been shaped by the larger stream of history. What is a home, and why does having one confer social entitlement, especially for white males? Hoboes were not the only transient workers. Transient streams also distributed Asian Americans and Mexican Americans throughout the West, for example. But in spite of insistent IWW rhetoric of racial inclusion, the streams were largely separate. Even where different races worked together, they tended to camp and socialize separately. They inhabited different social, cultural, and economic terrain. As with maleness, whiteness was a cornerstone of hobo identity and pride. While a white woman or an African American man might also have been 
homeless and transient, their conditions did not pose the same social and cultural dilemmas as were posed by the white man who failed to exercise his privilege and instead took to the open road. It remains unclear whether the hobo chose a rootless life or had it thrust upon him. Or whether he should be envied or pitied. Above all, respectable people wanted him placed in a stable and unthreatening social role: head of household.

The historical restlessness and continual westward flow of Americans dispersed rather than rooted the population. At the same time that railroads spread westward in the late nineteenth century, the "wageworkers' frontier" replaced what had once been celebrated as a land of opportunity for yeoman farmers. In the West, virtually all work was seasonal; and regular movement of laborers was both convenient and profitable for new agricultural, construction, mining, and forestry enterprises. In off seasons, with wages in their pockets, workers gravitated to lively main stems in cities, where they notoriously caroused and incubated radical politics. As in mainstream culture, the West in hobo ideology nurtured exuberant masculinity, but with hoboes this masculinity came in the form of a virile working class rather than the patriarchal privilege accruing to the industrious settler.

ALTHOUGH there are scattered references to Iowa in both books, it is not the focus of either. Higbie's map of cities discussed in his book (36) leaves lowa mostly blank. Sioux City had a main stem that branched out to the Dakota wheat fields, but there is little indication of a flow of Sioux City transients eastward into Iowa. Without the large wheat farms of the Dakotas, most Iowa farmers had more manageable harvest labor needs. Sugar beet and vegetable farmers tended to use Mexican labor, as did railroads in Fort Madison and Des Moines; and African Americans worked on railroads and in coal mines in various locations. Des Moines had a main stem, but it is mentioned only in passing and is not shown on the map.

In fact, Iowa scholars are entitled to cringe when reading Higbie's account of a hobo who caught a boxcar out of Clinton and headed for Chicago, beating, begging, and working his way across Iowa (173). For readers unversed in Iowa geography, Clinton is on the eastern border of Iowa, Illinois is east of Iowa, 
Chicago is on the eastern side of Illinois, and a train from Clinton to Chicago travels across Illinois, not Iowa. Also, although it is orthographically odd, "Denison" has no double $n$; Iowa has no town named "Dennison" (174).

While DePastino describes hoboes specifically in terms of the main stem base and hinterland jobs, Higbie is inclined to see more permeable boundaries between transient labor and local labor. Problems arise with this blending. Would local workers meet the same scorn and violence that hoboes faced in the towns of eastern South Dakota? Could local workers be as readily shortchanged in their wages as transients, who could be run out of town rather than staying put to badmouth the cheating employer? Did transients negotiate the same work agreements as Iowa locals? Surprisingly, at one point (52) Higbie goes further to deny any class difference between farmers and hired workers, although this undercuts much of his other material. Farmers were not like hobo workers in being "outcasts" from their community, as in the title of Higbie's book. Many had substantial respect and social power in rural communities. Farmers typically had families and dense networks of kinship ties and reciprocal obligations that were diametrically opposed to the unrooted and shifting relationships of the road.

Higbie is right that class delineation in the rural context is fluid and poorly defined. Yet Cecilia Danysk's study of the hired hand documents an increasing divide between the farm family and the hired hand in the late nineteenth and early twentieth century. Patrick Mooney's sociological analysis delineates diverse axes on which to assess the class positions of farmers. Farmers do not constitute a single class. Many farmers spent a period of their youth as hired workers, indicating economic differences within the masses of farmers and farm workers, but not implying that the typical farm worker was on the ladder to becoming self-employed. ${ }^{1}$

There may be substantive reasons why Iowa gets short shrift in these books. Called "the middle land," Iowa was historically a state of small towns, sturdy family farms, political moderation,

1. Cecilia Danysk, Hired Hands: Labour and the Development of Prairie Agriculture, 1880-1930 (Toronto, 1995); Patrick H. Mooney, "Toward a Class Analysis of Midwestern Agriculture," Rural Sociology 48 (1983), 563-84. 
and a comparative lack of economic polarity. With its exceptionally robust agricultural core, Iowa may have supported a different class structure than was present in neighboring states. Except perhaps in the 1930s, Iowa has never seen the radical revolts and social experiments that emerged in Plains states, nor has it sustained the level of labor organization historically present in Illinois and Minnesota. Yet such writing as the fiction of Ruth Suckow and Curtis Harnack's poignant description of the hired man on the northwest Iowa farm where he grew up in the 1930s provide telling clues to the presence of people for whom the touted agricultural ladder was not available. Taking the experience of the hired worker seriously may rearrange the prevailing image of Iowa's middle-class social structure. Further, a focus on the hired girl, the hired man, the bootlegger, the prostitute, and the casual laborer may lead to fresh insights into historical and economic processes in Iowa. If, in fact, the social and economic processes that characterized the hobo life were not present in Iowa, then why not? ${ }^{2}$

Where do we look to find the traces of transient and marginal workers in Iowa? Census documents have been valuable primary sources for studying the history of Iowa. Federal and state manuscript census schedules, open for study 75 years after the census date, offer a wealth of information on household composition, ethnicity, occupation, fertility variations, education, religion, languages spoken, and farming patterns. But what do they tell about floaters such as hoboes? House-tohouse census-takers undoubtedly missed many hoboes who were living on trains or in camps outside of towns. They recorded at most one occupation and one residence for each person. While this protocol would accurately characterize a broad swath of the middle class, it would over-simplify and misrepresent the lived experience of workers who were in and out of different kinds of jobs and workers who spent some of their time in cities and some in the country and who slept in a variety

2. Dorothy Schwieder, Iowa: The Middle Land (Ames, 1996), xi. Ruth Suckow, "The Daughter," in Iowa Interiors (New York, 1926), 37-49; Curtis Harnack, We Have All Gone Away (Ames, 1981), 91-101. See also Deborah Fink, Cutting into the Meatpacking Line: Workers and Change in the Rural Midwest (Chapel Hill, NC, 1998), 155-90. 
of makeshift and permanent shelters over the course of a year. Census records may actually obscure the presence of the hoboes discussed in these books.

Politicians, businessmen, artists, and professional people have tended to leave paper trails to help historians find them. The Iowa middle class had its club life, family gatherings, obituaries, and achievements recorded for posterity in local newspapers. Some middle-class persons left journals, diaries, and letters to tell their stories to those who came after them. Unions have provided remarkable accounts of the lives of their leaders in the Iowa Labor History Oral Project, housed at the State Historical Society of Iowa in Iowa City. This rich collection of information about the middle class and labor leaders may skew our thinking about the past and about people who did not leave the same kinds of traces of their lives.

To explore the terrain of general laborers in Iowa, we need to use historical documents critically to find their lives in records that slighted them. Careful reading and change of focus reveal information about the marginal working class, albeit seldom the same kind of information that is available for the middle class. Although disparaging and suspicious of social outsiders, many newspapers recorded quite a bit about casual and transient workers, often in the form of accounts of both men and women upsetting the peace and being arrested for vagrancy and other crimes. Court records provide further data. Churches, charitable organizations, the government, and academics often reached out to assess the conditions of the down-and-out and to assist them in various ways. While records of these activities depict the poor across a class divide, they add to the pool of information. Records of railroads, construction firms, and other businesses provide occasional clues about the lives of their workers. Interviews from the lowa Labor History Oral Project include many early-life experiences relating to rural and unorganized workers before they found their way to unions. Higbie and DePastino offer models of fine sleuthing in digging up sources, interrogating them, and extracting information.

THEIR BOOKS also make significant contributions to recent scholarly discussions on several larger issues. Both books, but 
especially DePastino's, contribute to recent scholarship on male identity and male-centered social patterns, presenting the predominant conventions as cultural constructs rather than as facts of nature. Likewise, the self-consciously male world of the hobo was created and maintained, in part, by rape and other sexual intimidation of women who might have traveled the road with their brothers-in-spirit. Even so, as with other "male worlds," women were present even though disregarded and disrespected. In spite of the disdain a man of the road had for women and domesticity, it was typically a housewife rather than a man who took pity on him and provided a meal when he begged. A few women hopped the freights disguised as men. Women were present in the brothels and bars of the main stems, and some of them raised children who entered the hobo stream. At least one of the rousing Wobbly organizers was a woman. Clearly hoboes didn't want to be bothered with lace doilies; but there must have been more women of like mind who would have taken to the road if allowed. Mexican migrant workers, for example, traveled in family groups and did some of the same work as hoboes, but with different gender arrangements. Gender studies on men's control of their space and their boundaries draw on and complement studies of women and gender.

The emergence of tramps in the aftermath of the Civil War, the suppression of IWW organizing during World War I, and the family-and-home retrenchment organized in the wake of World War II are instances of wars' reshuffling and reframing human possibilities beyond the actual arenas of physical carnage. Like war in general, these wars mobilized and celebrated males, concentrated wealth, intensified industrialization, and stifled dissent. More analysis needs to be done to fold historical waves of militarism into theories of gender, class, and social structure. The experiences of the most vulnerable men and women-the poor and unrooted-may constitute a revealing perspective on military processes.

As DePastino makes clear, the definition of home-and its counterpart, homelessness - is ideologically charged. In terms of prevailing middle-class expectations, it means not just a roof but also a defined and stable set of intimate relationships. But such an understanding is constructed, not given. Residential 
hotel districts, once found in every major city, functioned seasonally as homes of sorts to hoboes. Rather than upgrade such locations, post-World War II urban renewal removed them in favor of business construction and subsidies to suburban family housing. These hobo studies, by laying out an imagined alternative to family housing and civic organization, open new sets of questions about social formation and power.

The life of the open road has always had its cultural champions. Without romanticizing or excusing the pathologies of tramps, hoboes, and bums, we can acknowledge the poetry of their lives and ponder the shape and workings of the world as viewed from the bottom. 
Copyright of Annals of Iowa is the property of State of Iowa, by \& through the State Historical Society of Iowa and its content may not be copied or emailed to multiple sites or posted to a listserv without the copyright holder's express written permission. However, users may print, download, or email articles for individual use. 